\title{
西洋絵画における色・時間・季節の印象評価と心理的評価の関係性の分析 IMPRESSION EVALUATION OF COLOR, TIME AND SEASON IN WESTERN PAINTINGS ANALYSIS OF RELATIONSHIP OF PSYCHOLOGICAL EVALUATION
}

\author{
積田 洋*1, 渋谷沙季*2, 吉本美江 ${ }^{* 2}$ \\ Hiroshi TSUMITA, Saki SHIBUYA and Mie YOSHIMOTO
}

\begin{abstract}
In many cases, the method of expressing the architectural space is in a two-dimensional medium of photographs and perspectives. The perspective figure is effective for expressing the visual performance of the building.

For that reason study analyse the space painted on the European Art.When a person looks at European Painting, his/ her impression of a color, time, the season and the relations of the psychological evaluation are quantitatively studied. Therefore I clarify the influence that neighboring scenes and atmospheres which give in an impression in Architecture drawing. And it is intended to obtain basic information to improve architectural and spatial representation.
\end{abstract}

Keywords : Western Paintings, Psychological Evaluation, color, time, season, relationship, 西洋絵画, 心理的評価, 色彩, 時間, 季節, 関係性

\section{1. 研究背景 ·目的}

建築空間は 3 次元であるが、それらを表現する方法は写真やパー スなどの 2 次元の媒体で立体図法を用いて表現されることが多い。 その中でも後期ルネッサンスに確立した透視図は、直感的な理解が 容易であるため、建築がどのように見えるかを伝達するプレゼンテー ションの手段として有効といえる。立体図法による空間表現は主に 西洋絵画で用いられ、発達した手法である。発表研究では、西洋絵 画に描かれた建築要素の二次元的な構成の認知評価について報告し ている ${ }^{1)}$ 。これは、絵画を特徴づける印象深い要素を、その種類や印 象の強弱も含めて明らかにし、さらに要素の配置構成との関係を読 み取ることで、絵画の二次的表現において要素の配置構成上の意味 や構図の空間的広がり・奥行きとの関係を示した。さらに、西洋絵 画の心理的評価と構図の特性について報告を行った ${ }^{2) 3) 。 そ れ に よ り 、 ~}$ 西洋絵画の心理的評価は、印象に残る構成要素とその配置、画面の 奥行きの広がりと関係していることが明らかになった。

本研究では、発表研究で得られた心理的評価分析注1) の結果を用い て、心理的評価と色、時間、季節の関係を明らかにするものである。

二次元的な空間の表現の中には単体の建築を表現しただけでなく、 それが立地する環境や風景の関係から空間を表現したものも含まれ る。この場合は建築はほかの描かれたものとともに構成要素の一つ
となり、それらの相互関係が空間を表現している。

透視図という２次元で表現された空間が、様々な枠組みスケール、 構成要素に応じてどのように認識されるのかを明らかにするため、 本研究では初期段階として西洋絵画を対象とし、人が絵画を鑑賞し た時の色、時間、季節の印象に着目し、心理的評価の関係を知るこ とで、周辺の情景、雾囲気が二次元での表現としてどのような影響 を与えるのかを明らかにすることにより、建築パースを描く際見る 人に意図した印象を与えられるかの伝達力を高める手がかりにする 空間表現の基礎的知見を得ることを目的とする。

\section{2. 既往研究の概要}

絵画と描かれている空間に関しての研究は、芸術学や美術史学の 分野において広く行われているが、建築分野から西洋絵画の空間に ついて探った研究は比較的少ない。筆者らの発表研究のほか、様及 な遠近法を幾何学的や視覚の観点から論じた黒田正巳の研究 ${ }^{5)} 、 15$ 世紀から 19 世紀までの西洋絵画全般や特定の地域、作家を対象とし て、描かれているジャンルや構成要素と距離や面積について分析し た若山滋らの一連の研究 ${ }^{6}{ }^{6}$ がある。建築空間の 2 次元表現に関しては、 F. L. ライト住宅の透視図を分析し類型化した坪山幸王らの研究 ${ }^{7)} や$ 実際の建物と西洋絵画に描かれた透視画の空間特有の相違点を探っ

\footnotetext{
*1 東京電機大学未来科学部建築学科 教授. 工博

$* 2$ 東京電機大学大学院未来科学研究科 大学院生.工修

Prof., Dept. of Architecture, School of Science and Technology for Future, TDU, Dr.Eng. Grad. Student, Dept. of Architecture, Faculty of Science and Technology for Future, TDU, M.Eng.
} 
た福留吉絵らの研究 ${ }^{8)}$ がある。本研究は、主として絵画的表現技法 そのものを报った上記の諸研究とは視点を異にし、周辺の情景と見 る人に与える印象評価を数量的関係としてとらえようとするもので ある（Fig. 1)。

\section{3. 対象絵画の選定}

分析対象の選定は、発表研究と同じく米国と日本の高等教育で 西洋美術史の教科書として定評がある、『Janson's History of Art:Western Tradition』の8 版 ${ }^{9)}$ 、『Gardner's Art Through Ages』 の 12 版 ${ }^{10)}$ 、『カラー版 西洋美術史』 ${ }^{11)}$ 、『高校美術 1 ・2』 ${ }^{12)}$ に刑 されている絵画のうち、ルネッサンスから近代までの間で建築物が 描きこまれた全ての具象画の中から選定する。内部空間も重要な建 築の空間であるが、外観と内部空間では表現されている空間の性質 が異なるため、同一の実験では評価困難であるため、外観が描かれ ている絵画を分析対象とした。建物の外観は、一部がクローズアッ プされているものや、円形に群として描かれているものなど様々な ケースが含まれる。宗教画は特別な形態があるため対象から除外し た。また、個別の作家に偏らないように、一画家あたり一作品とし た結果、対象絵画は 39 作品とした（Table 1)。

\section{4. 印象評価実験注 2}

周辺の情景、䨌囲気の変化によって「色」「時間」「季節」印象に どのような変化が現れるのか知るため、印象評価実験 ${ }^{13) 14)}$ を行った。 実験の方法は、対象絵画の画像を原寸大に出力し、絵の中央から床 が $1500 \mathrm{~mm}$ の高さになるように掲示して、50 名の被験者注 ${ }^{3)}$ に、絵 画の対角線の 2 倍の距離から鑑賞してもらい実験を行った。まず、色」 については全体的な色の印象については絵画全体の見た目の色の印 象を自由記述で答えてもらい。「時間」については一日のいつ頃なの か［早朝］［朝］［昼］［夕方］［夜］［その他］から選択してもらった。 「季節」については［春］［夏］［秋］［冬］［その他］から選択してもらっ た。そして、各絵画において「色」、「時間」、「季節」の印象につい て集計した。

\section{4-1. 色彩の印象評価分析}

1 人 1 色から 5 色の指摘があり、 1 人平均 1.29 色の指摘があった。 指摘された色はできるだけ被験者の挙げた名称のまま種別を行った。 注4）その結果、［赤］［赤茶］［橙］［茶］［黄色］［黄緑］［緑］［青緑］ ［水色］［青］［紫］［白］［黒］［灰色］などの 24 色（Fig. 2）（Fig. 3) で、特に［緑］の指摘が多く 399 の指摘があった。また、[黒］（指 摘数 272）[白）（指摘数 271）[青］（指摘数 268）も多く指摘された。 各絵画の 24 色の指摘数を類似度としてクラスター分析（最遠隣法） 注 5) を行った (Fig. 4)。その結果を融合距離 12 で 6 タイプに類型化 した。これから【STW】【GLE】など 12 点の [緑］が多く指摘された タイプを「緑印象型」とした。このタイプは [緑] の指摘数 399 の うち $73 \%$ 指摘されている。【ESM】【VIR】など 4 点の［赤］の指摘が 多いタイプを「赤印象型」とした。このタイプは［赤］の指摘数 216 のうち $57 \%$ 指摘されている。さらに、【UTR】【SAS】などの $[$ 黒］［白］ [茶］など 9 点の彩度の低い色の指摘が多いタイプを「低彩度印象型」 とした。このタイプは［黒］の指摘数 272 のうち $24 \%$ 、[白］の指摘 数 271 のうち $40 \%$ 、[灰色］の指摘数 146 のうち $56 \%$ 、[茶］の指摘 数 167 のうち 60\%指摘されている。【AOS】【EM】[赤][茶][緑][青][白］

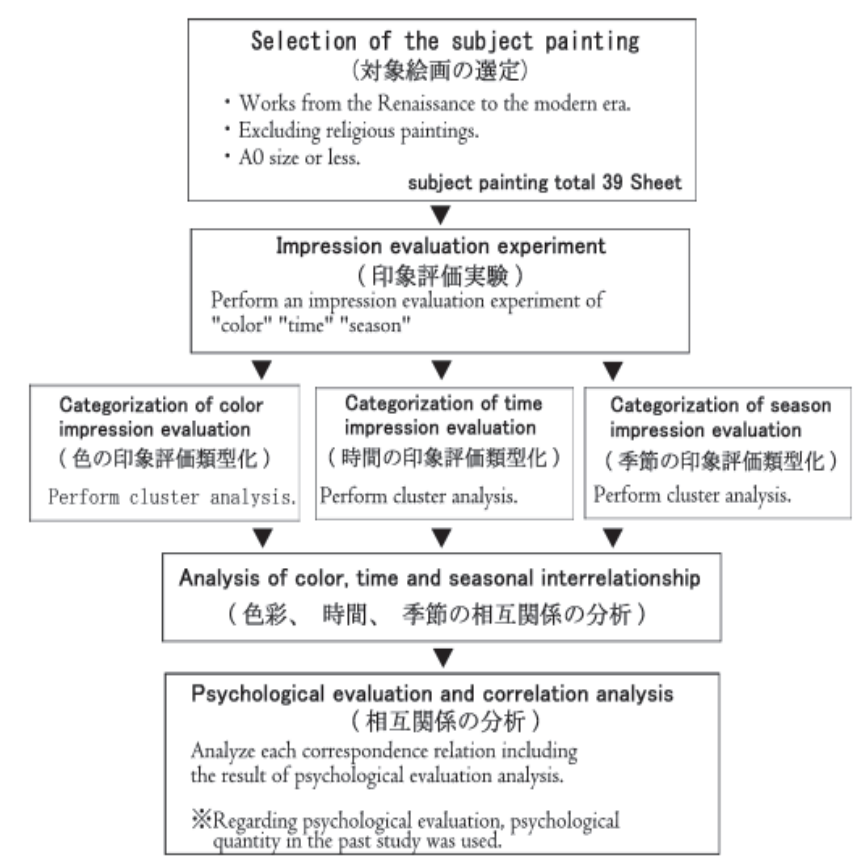

Fig. 1 Research flow

Table 1 Experimental painting list

\begin{tabular}{|c|c|c|c|}
\hline 記号 & タイトル & 画家 & 年代 \\
\hline TEM & The Tempest & Giordione & 1510 \\
\hline JOP & The Judgement of Paris & Cranach the Elder & 1528 \\
\hline BLB & Blind Leading Blind & Bruegel the Elder & 1568 \\
\hline AOS & Allegory of Sight & Jan Bruneghel the Elder & 1617 \\
\hline UTR & Pekus Gate Near Utrecht & van Goyen & 1646 \\
\hline PAS & A Pastral Landscape & Lorrain & 1648 \\
\hline VDE & View of Delft & Vermeer & 1661 \\
\hline HAA & Breaching Grounds Near Haarlem & Ruisdael & 1670 \\
\hline AMH & The Avenue at Middelharnis & Hobbema & 1689 \\
\hline MEZ & Mezzetin & Watteau & 1718 \\
\hline $\mathrm{BMO}$ & The Bucintoro at the Molo & Canaletto & 1732 \\
\hline SBB & Soap Bubbles & Chardin & 1733 \\
\hline TSW & The Swinng & Fragonard & 1772 \\
\hline $\mathrm{OMD}$ & The Old Man and Death & Joseph Wright & 1773 \\
\hline $\mathrm{CPC}$ & Cornelia Presenting Her Children & Kauffmann & 1785 \\
\hline VOR & View of Rome & Corot & 1827 \\
\hline GLE & The Gleaners & Millet & 1857 \\
\hline BEB & Beata Beatrix & Rossetti & 1863 \\
\hline SEI & On the Bank of the Seine & Monet & 1868 \\
\hline MAX & Max Schmitt in a single Scull & Eakins & 1871 \\
\hline STW & Snap the Whip & Homer & 1872 \\
\hline VSE & Villa at the Seaside & Morisot & 1874 \\
\hline HRU & The House at Rueil & Manet & 1882 \\
\hline GRO & The Sacred Grove & Chavannes & 1884 \\
\hline MSV & Mont Saite-Victoire & Cezanne & 1887 \\
\hline GWG & Gray Weather, Grande Jatte & Seurat & 1888 \\
\hline THA & The Harvest & van Gogh & 1888 \\
\hline SCR & The Scream & Munch & 1893 \\
\hline PTF & La Place du Theatre & Pissarro & 1898 \\
\hline LRE & Landscape with Red Trees & Maurice de Vlaminck & 1907 \\
\hline SAS & Sixth Avenue and 30th Street & Sloan & 1909 \\
\hline MMS & Mystery and Melancholy of a Street & de Chirico & 1914 \\
\hline VIR & Villa R & Klee & 1919 \\
\hline KIP & Kizette in Pink & Tamara de Lempicka & 1926 \\
\hline MEG & My Egypt & Demuth & 1927 \\
\hline NYN & New York, Night & O'Keeffe & 1929 \\
\hline $\mathrm{AGO}$ & American Gothic & Wood & 1930 \\
\hline ESM & Early Sunday Morning & Hopper & 1930 \\
\hline $\mathrm{CHW}$ & Christina's World & Andrew Wyeth & 1948 \\
\hline
\end{tabular}


[灰]など 7 点の色の指摘が多様であるタイプを「多色印象型」と呼ぶ。 【THA】【LRE】など 3 点の [黄色]の指摘が多いタイプを「黄色印象 型」と呼ぶ。このタイプは［黄色］の指摘数 184 のうち $44 \%$ 指摘さ れている。【AGO】【BEB】など 4 点の [黒］の指摘の多いタイプを「黒 印象型」と呼ぶ。このタイプは [黒] の指摘数 272 のうち $44 \%$ 指摘 されている。

\section{4-2. 時間の印象評価分析}

「時間」の集計においては、絵画がどの時間帯の印象であるかを [早 朝］［朝］［昼］［夕方］［夜］［その他］の中から選択してもらった。 特に［昼］の指摘が多く 620 の指摘があった。また［夕方］も指摘 数 570 と多く指摘された。以上 6 つ指摘数を類似度としてクラスター 分析（最遠隣法）を行った（Fig. 5)。その結果を融合距離 6 で 5 タ イプに類型化した。これから【MEZ】【UTR】など 7 点の［早朝］［朝］ の指摘が多いタイプを「朝印象型」とした。このタイプは [早朝] の指摘数 187 のうち $51 \%$ 、[朝］の指摘数 378 のうち $21 \%$ 指摘され ている。【MEG】【HRU】など 15 点の［朝］［昼］の指摘が多いタイプ を「朝昼印象型」とした。このタイプは［朝］の指摘数 387 のうち $57 \%$ 、[昼］の指摘数 620 のうち $58 \%$ 指摘されている。【SAS】【CHW】 など 9 点の [昼］［夕方］の指摘が多い「昼夕印象型」とした。この タイプは [昼］の指摘数 620 のうち $32 \%$ 、[夕方］の指摘数 570 のう ち 30\%指摘されている。【PAS】【SCR】など 5 点の [夕方］の指摘が 多いタイプを「タ方印象型」とした。このタイプは [夕方 ] の指摘 数 570 のうち $36 \%$ 指摘されている。【VIR】【NYN】など 3 点の [夜］ の指摘が多いタイプを「夜印象型」と呼ぶ。このタイプは［夜］の 指摘数 176 のうち $75 \%$ 指摘されている。

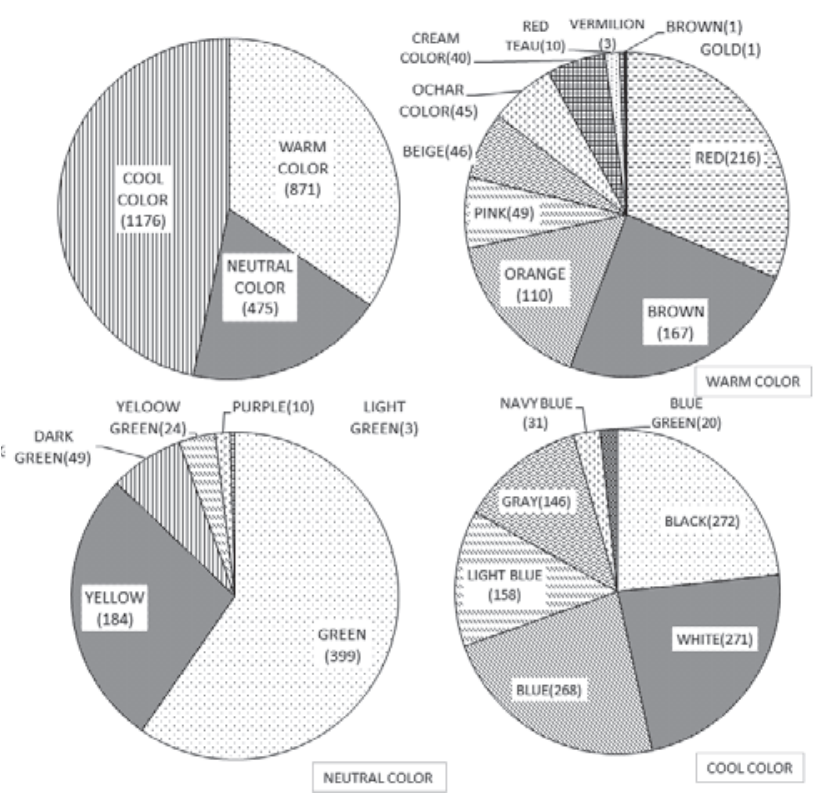

Fig. 2 The indicated color

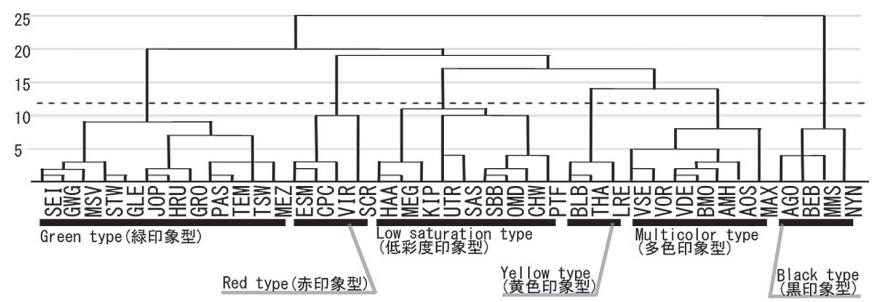

Fig. 4 Impression evaluation experiment of color Experiment cluster diagram

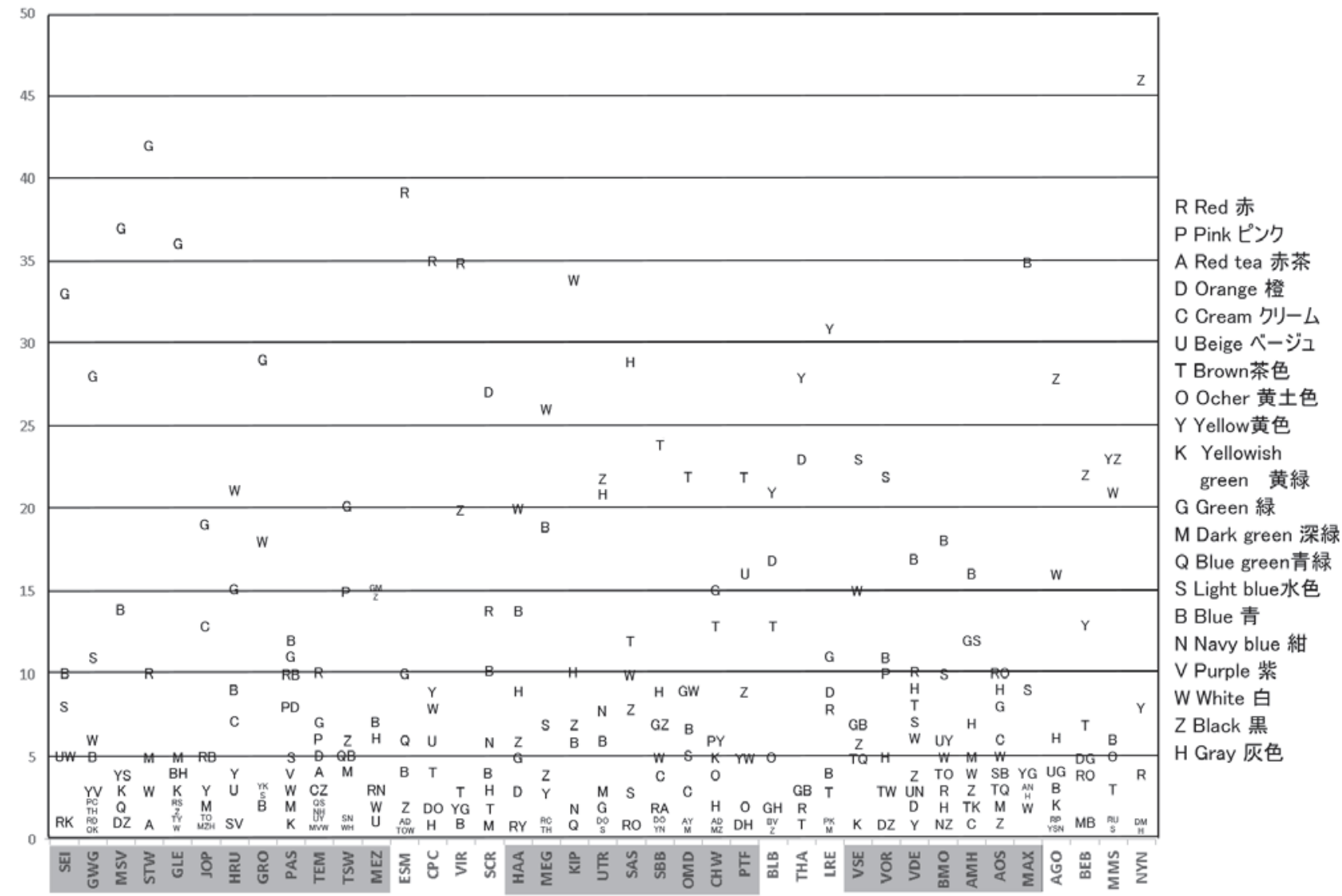

Fig. 3 Number of color indications 


\section{4-3. 季節の印象評価分析}

「季節」の印象評価については、絵画がどの季節の印象であるかを [春］［夏］［秋］［冬］［その他］の中から選択してもらった。特に［夏］ の指摘が多く580 の指摘があった。また［秋］も指摘数 544 と多く 指摘された。以上 5 つ指摘数を類似度としてクラスター分析（最遠 隣法）を行った（Fig. 6)。その結果を融合距離 7 で 5 タイプに類型 化した。これから【KIP】【SEI】など 11 点の［夏］の指摘が多い夕 イプを「夏印象型」とした。このタイプは［夏］の指摘数 580 の中 322 指摘されている。【TSW】【GWG】など 5 点の［春］の指摘が多い夕 イプを「春印象型」とした。このタイプは［春］の指摘数 380 の中 119 指摘されている。【SCR】【BEB】など 14 点の［秋］［冬］の指摘 の多いタイプを「秋冬印象型」とした。このタイプは［秋］の指摘 数 545 の中 256、[冬］の指摘数 430 の中 180 指摘されている。【BLB】 【THA】【CHW】の 3 点は [秋］の指摘が多いタイプの「秋印象型」と した。このタイプは[秋］の指摘数 544 の中 122 指摘されている。【PTF】 【NYN】など 6 点の [冬］の指摘が多いタイプを「冬印象型」とした。 このタイプは [冬］の指摘数 430 の中 196 指摘されている。

\section{5. 色、時間、季節の相互関係}

色の印象評価、時間の印象評価、季節の印象評価、そして心理評価 のそれら 4 つの関係を考察するため、それぞれの類型の相互関係を マトリックスとして表現して分析した。

\section{5-1. 色と時間の印象の相互関係}

色と時間の印象評価については、「多色印象型」の絵画 7 点のうち 6 点が「朝昼印象型」となった。これは多くの色が認知できることで 明るい時間の印象になることが言える。「黄色印象型」は 3 点あるう ち 2 点は「昼夕印象型」、1 点は「夕方印象型」であった。このことから、 ［黄色］はいわゆるたそがれの［夕方］の印象になる傾向があるとい える。また、緑印象型」は 12 点のうち 5 点が「朝印象型」 4 点が「朝 昼印象型」であった。「低彩度印象型」は 9 点のうち 3 点が「朝昼印 象型」、4点が「昼夕印象型」であった。そのほかの「赤印象型」「黒 印象型」については分散していた（Table 2)。

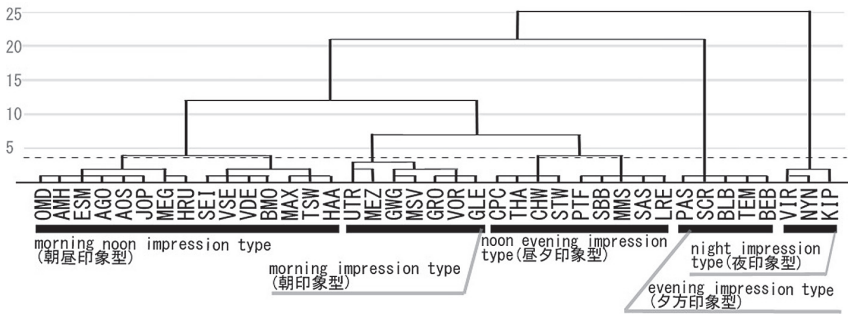

Fig. 5 Impression evaluation experiment of time Cluster diagram

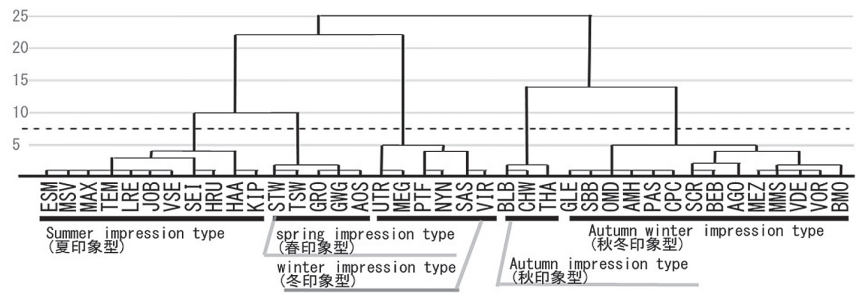

Fig. 6 Seasonal Impression Evaluation Experiment Cluster Diagram

\section{5-2. 色と季節の印象の相互関係}

色と季節の印象評価については「春印象型」が 5 点ある絵画のう ち 4 点が「緑印象型」であったことから、[春］の印象は［緑］の印 象が強いことがわかる一方で、「緑印象型」は 12 点のうち 4 点は「春 印象型」、5 点は「夏印象型」、3 点は「秋冬印象型」と分散している ため、[緑］の印象のみでは季節の印象は判断できない。また、「黒 印象型」は 4 点あるうち 3 点が「秋冬印象型」、1 点が「冬印象型」 と偏っているため、［黒］の印象が強いと［秋］と［冬］の印象にな る傾向がある (Table3)。

5-3. 時間と季節の印象の相互関係

時間と季節の印象評価については、「朝昼印象型」の「夏印象型」 の絵画が 7 点多い以外は全体的に分散しており、時間と季節の内容 は多様である（Table 4)。

Table 2 Correlation between color and time

\begin{tabular}{|c|c|c|c|c|c|}
\hline Time & $\begin{array}{c}\text { morning noon } \\
\text { impression type } \\
\text { (朝昼印象型) }\end{array}$ & $\begin{array}{c}\text { noon evening } \\
\text { impression type } \\
\text { (昼夕印象型) }\end{array}$ & $\begin{array}{c}\text { morning } \\
\text { impression type } \\
\text { (朝印象型) }\end{array}$ & $\begin{array}{c}\text { evening } \\
\text { impression type } \\
\text { (夕方印象型) }\end{array}$ & $\begin{array}{c}\text { night } \\
\text { impression type } \\
\text { (夜印象型) }\end{array}$ \\
\hline $\begin{array}{c}\text { Green type } \\
\text { (緑印象型) }\end{array}$ & $\begin{array}{c}\text { HRU SEI } \\
\text { JOP TSW }\end{array}$ & STW & $\begin{array}{l}\text { MSV GRO } \\
\text { GWG GLE MEZ }\end{array}$ & PAS TEM & \\
\hline $\begin{array}{c}\text { Low saturation } \\
\text { type } \\
\text { (低彩度印象型) }\end{array}$ & $\begin{array}{c}\text { MEG HAA } \\
\text { OMD }\end{array}$ & $\begin{array}{c}\text { CHW PTF } \\
\text { SBB SAS }\end{array}$ & UTR & & KIP \\
\hline $\begin{array}{c}\text { Multicolor type } \\
\text { (多色印象型) }\end{array}$ & $\begin{array}{l}\text { AOS BMO VDE } \\
\text { MAX VSE AMH }\end{array}$ & VOR & & VIR \\
\hline $\begin{array}{c}\text { Red type } \\
\text { (赤印象型) }\end{array}$ & ESM & CPC & & SCR & NYN \\
\hline $\begin{array}{c}\text { Black type } \\
\text { (黒印象型) }\end{array}$ & AGO & MMS & & BEB & \\
\hline $\begin{array}{c}\text { Yellow type } \\
\text { (黄色印象型) }\end{array}$ & & THA LRE & & BLB & \\
\hline
\end{tabular}

Table3 Correlation between color and season

\begin{tabular}{|c|c|c|c|c|c|}
\hline Color & $\begin{array}{c}\text { Season } \\
\text { impression type } \\
\text { (秋冬印象型) }\end{array}$ & $\begin{array}{c}\text { Summer } \\
\text { impression type } \\
\text { (夏印象型) }\end{array}$ & $\begin{array}{c}\text { winter } \\
\text { impression type } \\
\text { (冬印象型) }\end{array}$ & $\begin{array}{c}\text { Spring } \\
\text { impression type } \\
\text { (春印象型) }\end{array}$ & $\begin{array}{c}\text { Autumn } \\
\text { impression type } \\
\text { (秋印象型) }\end{array}$ \\
\hline $\begin{array}{c}\text { Green type } \\
\text { (緑印象型) }\end{array}$ & $\begin{array}{c}\text { GLE MEZ } \\
\text { PAS }\end{array}$ & $\begin{array}{c}\text { HRU SEI JOP } \\
\text { MSV TEM }\end{array}$ & & $\begin{array}{c}\text { TSW GRO } \\
\text { GWG STW }\end{array}$ & \\
\hline $\begin{array}{c}\text { Low saturation } \\
\text { type } \\
\text { (低彩度印象型) }\end{array}$ & OMD SBB & HAA KIP & $\begin{array}{c}\text { MEG UTR } \\
\text { PTF SAS }\end{array}$ & & CHW \\
\hline $\begin{array}{c}\text { Multicolor type } \\
\text { (多色印象型) }\end{array}$ & $\begin{array}{c}\text { BMO VDE } \\
\text { AMH VOR }\end{array}$ & MAX VSE & & AOS & \\
\hline $\begin{array}{c}\text { Red type } \\
\text { (赤印象型) }\end{array}$ & CPC SCR & ESM & VIR & & \\
\hline $\begin{array}{c}\text { Black type } \\
\text { (黒印象型) }\end{array}$ & $\begin{array}{c}\text { AGO MMB } \\
\text { BEB MMS }\end{array}$ & NYN & & & THA BLB \\
\hline $\begin{array}{c}\text { Yellow type } \\
\text { (黄色印象型) }\end{array}$ & & LRE & & & \\
\hline
\end{tabular}

Table 4 Correlation between time and season

\begin{tabular}{|c|c|c|c|c|c|}
\hline Season & $\begin{array}{c}\text { morning noon } \\
\text { impression type } \\
\text { (朝昼印象型) }\end{array}$ & $\begin{array}{c}\text { noon evening } \\
\text { impression type } \\
\text { (昼夕印象型) }\end{array}$ & $\begin{array}{c}\text { morning } \\
\text { impression type } \\
\text { (朝印象型) }\end{array}$ & $\begin{array}{c}\text { evening } \\
\text { impression type } \\
\text { (夕方印象型) }\end{array}$ & $\begin{array}{c}\text { night } \\
\text { impression type } \\
\text { (夜印象型) }\end{array}$ \\
\hline $\begin{array}{c}\text { Autumn winter } \\
\text { impression type } \\
\text { (秋冬印象型) }\end{array}$ & $\begin{array}{l}\text { OMD BMO VDE } \\
\text { AMH AGO }\end{array}$ & CPC SBB MMS & GLE MEZ VOR & PAS SCR BEB & KIP \\
$\begin{array}{c}\text { Summer } \\
\text { impression type } \\
\text { (夏印象型) }\end{array}$ & $\begin{array}{l}\text { HRU SEI JOP } \\
\text { ESM HAA MAX } \\
\text { VSE }\end{array}$ & STW & MSV & TEM & VIR NYN \\
\hline $\begin{array}{c}\text { winter } \\
\text { impression type } \\
\text { (冬印象型) }\end{array}$ & MEG & CHW THA & UTR & & \\
\hline $\begin{array}{c}\text { Spring } \\
\text { impression type } \\
\text { (春印象型) }\end{array}$ & TSW AOS & LRE & GRO GWG & & \\
\hline $\begin{array}{c}\text { Autumn } \\
\text { impression type } \\
\text { (秋印象型) }\end{array}$ & PTF SAS & & BLB & \\
\hline
\end{tabular}


6. 心理的評価との色 · 時間 - 季節との相互関係

心理的評価と色の印象評価の関係を考察する。なお心理的評価分析

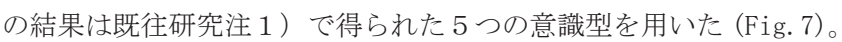

6-1. 心理的評価と色の印象評価の関係性分析

「緑印象型」は、12 点の絵画のうち 8 点が $<$ 田園的な感じ $><$ 広々 とした感じ ><澄んだ感じ>の評価が高い「快適田園型」である。 それ以外の 4 点は「緑」以外に［赤］や［青］［黒］など印象の強い 色が配置されているためほかの〈意識型〉となった。「また、「低彩 度印象型」の絵画のうち [茶］の指摘が多いものが「弱印象都会型」、 [白］［灰色］の指摘が多いものが「閉鎖的都会型」、[黒］［灰色］の 指摘が多い絵が「静的暗狭型」になっている。「多色印象型」は 7 点
の絵画のうち、とくに空や水面が多い絵画は＜明るい感じ $><$ 広々 した感じ $><$ 澄しだ感じ $>$ の評価が高い「快適田園型」に、多くの 色が配置された絵画は＜明るい感じ＞の評価が高い「弱印象都会型 にまとまっている。このことから、多くの色を使うことでく明るい 感じ>の評価になる傾向があると分かる。「赤印象型」4 点の絵画の うち「弱印象都会型」の 2 点以外は寒色の指摘が 20 以上あった。「黒 印象型」は縦長の構図で、4 点のうち 2 点が「静的暗狭型」、2 点 が「閉鎖的都会型」にまとまっていた。「静的暗狭型」と「閉鎖的都 会型」は＜暗い感じ $><$ 狭い感じ $><$ 濁った感じ $>$ の評価が高い「黒 印象型」以外でそれらの意識型に属している絵画も他と比べて [ 黒 ] [ 灰色］の印象が強い絵画が多かったことから、これらの印象が強

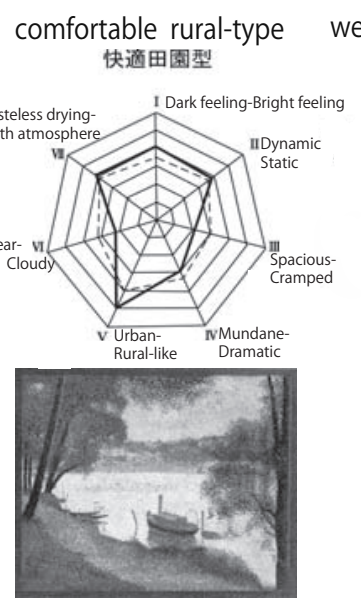

GWG (nsion urban-type 弱印象都会型
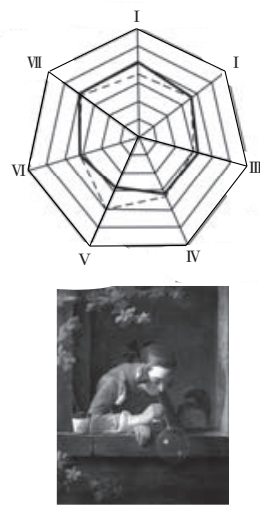

SBB closed urban-type static narrow dark type Dramatic rural type 開鎖的都会型 静的暗狭型 ドラマティック田園型
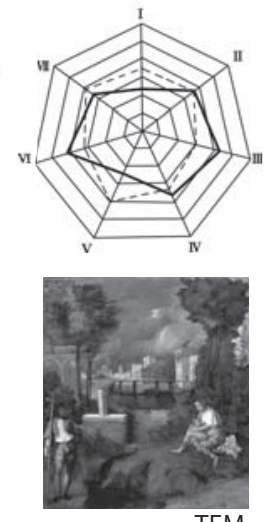

TEM
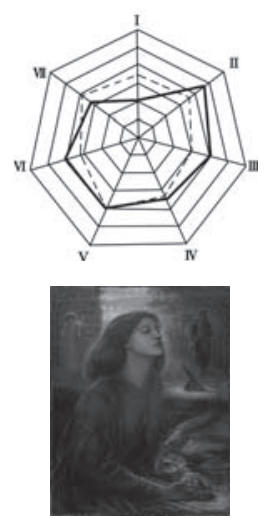

$\mathrm{BEB}$
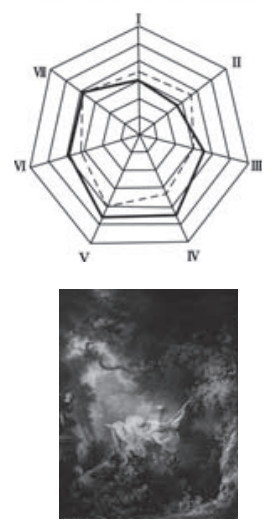

TSW

Fig.7 An example of psychological evaluation

\begin{tabular}{|c|c|c|c|c|c|}
\hline Color & $\begin{array}{l}\text { comfortable } \\
\text { rural-type } \\
\text { (快適田園型) }\end{array}$ & $\begin{array}{c}\text { weak impression } \\
\text { urban-type } \\
\text { (弱印象都会型) }\end{array}$ & $\begin{array}{c}\text { closed } \\
\text { urban-type } \\
\text { (閉鎖的都会型) }\end{array}$ & $\begin{array}{c}\text { static narrow } \\
\text { dark type } \\
\text { (静的暗狭型) }\end{array}$ & $\begin{array}{l}\text { Dramatic } \\
\text { rural type } \\
\text { (ドラマティク㨬型) }\end{array}$ \\
\hline $\begin{array}{l}\text { Green type } \\
\text { (緑印象型) }\end{array}$ & 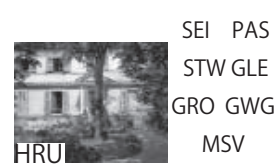 & & 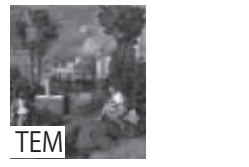 & $\frac{\mathrm{B}}{\mathrm{MEZ}}$ & Jopis \\
\hline $\begin{array}{c}\text { Low saturation } \\
\text { type } \\
\text { (低彩度印象型) }\end{array}$ & $\begin{array}{ll}\text { is } & \text { CHW } \\
\text { HAA } \\
\text { OMD }\end{array}$ & 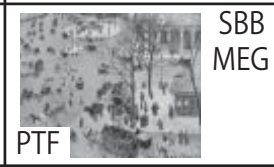 & $\begin{array}{l}\text { KIP } \\
\text { SAS }\end{array}$ & UTR & \\
\hline $\begin{array}{l}\text { Multicolor type } \\
\text { (多色印象型) }\end{array}$ & AMH if & 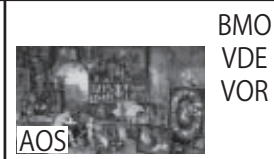 & & & \\
\hline $\begin{array}{l}\text { Red type } \\
\text { (赤印象型) }\end{array}$ & & $\operatorname{CPC}^{\mathrm{ES}}$ & VIP & & SCR \\
\hline $\begin{array}{l}\text { Black type } \\
\text { (黒印象型) }\end{array}$ & & & $\begin{array}{l}\text { MMS } \\
\text { NYN }\end{array}$ & $\overline{B E B}$ & \\
\hline $\begin{array}{l}\text { Yellow type } \\
\text { (黄色印象型) }\end{array}$ & $\begin{array}{l}\text { Pestind } \\
\text { THA }\end{array}$ & LRE & & & BLB \\
\hline
\end{tabular}

Fig. 8 Correlation between psychological evaluation and impression evaluation of color 
いと＜暗い感じ $><$ 狭い感じ $><$ 濁った感じ $>$ な゙の評価が高くな る傾向があると分かる。「黄色印象型」は全て横長の構図であった (Fig. 8)。

\section{6-2. 心理的評価と時間の印象の関係性分析}

心理的評価と時間の印象評価については、「弱印象都会型」の 10 点の絵画の 5 点が「朝昼印象型」、4 点が「昼夕印象型」に、「快適 田園型」の 15 点のうち 4 点が「朝昼印象型」、7 点が「昼印象型」、 3 点が「昼夕印象型」にまとまった、このことから明るい時間印象で あるとポジティブな印象になることが分かる。「夜印象型」の 3 点は 「閉鎖的都会型」にまとまった。このことから時間印象が［夜］であ ると＜暗い感じ $><$ 狭い感じ $><$ 濁った感じ $>$ な゙のネガティブな 印象になることが分かる (Table5)。

\section{6-3. 心理的評価と季節の印象の関係性分析}

心理的評価と季節の印象評価ではまず、〈都会的な感じ〉の印象が 強い「弱印象都会型」である 10 点の絵画のうち半数の絵画が「秋冬 印象型」であった。これは、「弱印象都会型」が樹木が描かれていな かったり、枯れ木であったり、樹木の存在が薄くなっいるからだと 考えられる。つまり、樹木が青々と生い茂っていると見る人の意識 は建物よりも、樹木による影響が強いことが分かる。しかし、く明 るい感じ $><$ 広々した感じ $><$ 澄んだ感じ $>$ な゙ポジティブな評価 が高い「快適田園型」は、「夏印象型」分類された絵画が一番多く、「冬 印象型」に分類された絵画はない。このことから樹木などの自然が 描かれることでポジティブな印象になることが分かる（Table6）。

Table5 Correlation between psychological evaluation and impression evaluation of time

\begin{tabular}{|c|c|c|c|c|c|}
\hline $\begin{array}{l}\text { Psychological } \\
\text { Time }\end{array}$ & $\begin{array}{c}\text { comfortable } \\
\text { rural-type } \\
\text { (快適田園型) }\end{array}$ & \begin{tabular}{|c|} 
weak impression \\
urban-type \\
(弱印象都会型)
\end{tabular} & $\begin{array}{c}\text { closed } \\
\text { urban-type } \\
\text { (閉鎖的都会型) }\end{array}$ & $\begin{array}{c}\text { static narrow } \\
\text { dark type } \\
\text { (静的暗狭型) }\end{array}$ & $\begin{array}{c}\text { Dramatic } \\
\text { rural type } \\
\text { ドラマテイック田園型 }\end{array}$ \\
\hline $\begin{array}{l}\text { morning noon } \\
\text { impression type } \\
\text { (朝昼印象型) }\end{array}$ & 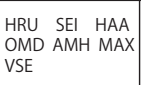 & $\mid \begin{array}{lll}\text { ESM } & \text { MEG } & \text { AOS } \\
\text { BMO } & \text { VDE } & \end{array}$ & & AGO & JOP TSW \\
\hline $\begin{array}{c}\text { noon evening } \\
\text { impression type } \\
\text { (昼夕印象型) }\end{array}$ & $\begin{array}{l}\text { STW CHW } \\
\text { THA }\end{array}$ & $\begin{array}{ll}\text { CPC } & \text { PTF } \\
\text { SBB } & \text { LRE }\end{array}$ & SAS MMS & & \\
\hline $\begin{array}{c}\text { morning } \\
\text { impression type } \\
\text { (朝印象型) }\end{array}$ & $\begin{array}{ll}\text { GLE } & \text { GRO } \\
\text { GWG } & \text { MSV }\end{array}$ & VOR & & MEZ UTR & \\
\hline $\begin{array}{c}\text { evening } \\
\text { impression type } \\
\text { (夕方印象型) }\end{array}$ & PAS & & TEM & BEB & SCR BLB \\
\hline $\begin{array}{l}\text { night } \\
\text { impression type } \\
\text { (夜印象型) }\end{array}$ & & & VIR KIP NYN & & \\
\hline
\end{tabular}

Table6 Correlation between psychological evaluation and seasonal

\begin{tabular}{|c|c|c|c|c|c|}
\hline Season & 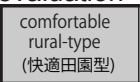 & 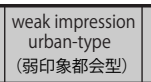 & $\begin{array}{c}\text { closed } \\
\text { urban-type } \\
\text { (開鎖的都会型) }\end{array}$ & $\begin{array}{c}\text { static narrow } \\
\text { dark type } \\
\text { (静的暗㹨型) }\end{array}$ & 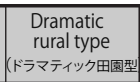 \\
\hline $\begin{array}{c}\text { Autumn winter } \\
\text { impression type } \\
\text { (秋冬印象型) }\end{array}$ & $\begin{array}{l}\text { OMD AMH } \\
\text { GLE PAS }\end{array}$ & $\mid \begin{array}{lll}\text { BMO } & \text { VDE } & \text { VOR } \\
\text { CPC } & \text { SBB }\end{array}$ & MMS & AGO MEZ BEB & SCR \\
\hline $\begin{array}{c}\text { Summer } \\
\text { impression type } \\
\text { (夏印象型) }\end{array}$ & $\begin{array}{l}\text { HRU } \\
\text { SEI HAA } \\
\text { MAX VES } \\
\end{array}$ & ESM LRE & TEM KIP & & JOP \\
\hline \begin{tabular}{|c|} 
winter \\
impression nype \\
(终纪象型)
\end{tabular} & & MEG PTF & SAS VIR NYN & UTR & \\
\hline \begin{tabular}{|c|} 
Spring \\
impression type \\
(春印象型)
\end{tabular} & GRO GWG STW & AOS & & & TSW \\
\hline $\begin{array}{c}\text { Autumn } \\
\text { impression type } \\
\text { (秋印象型) }\end{array}$ & GHW THA & & & & BLB \\
\hline
\end{tabular}

\section{7. まとめ}

西洋絵画に描かれた空間注6) から受ける心理的評価と色、時間、季 節の印象評価との関係を明らかにするために、39 点の西洋絵画につ いて、色、時間、季節の印象評価実験を行った。分析結果を以下に まとめる。

1) 対象絵画から受ける色の印象を調べた結果。24の色が指摘され、 特に緑の指摘が多く 399 の指摘があった。

2 ) 心理的評価の類型化との対応を見るため、色、時間、季節の印象 評価実験の結果を基にクラスター分析を行い類型化した。

(1)色については、該当の絵画数の多い順に「緑印象型」(12 作品)、「低 彩度印象型」(4 作品)、「多色印象型」（7 作品）、「赤印象型」（4 作品）、 「黒印象型」(4 作品)、「黄色印象型」(2 作品) の 6 タイプに分類した。 (2)時間でも、同様に「朝昼印象型」(15 作品)、「昼夕印象型」(9 作品)、 「朝印象型」（7 作品）、「夕方印象型」（5 作品）、「夜印象型」(3 作品) の 5 タイプに分類された。

(3)季節では、「秋冬印象型」(14 作品)、「夏印象型」(11 作品)、「冬印象型」 (6 作品)、「春印象型」（5 作品）、「秋印象型」（3 作品）の 5 タイプに 分類しそれぞれの特徴を示した。

3 ) 色の印象評価、時間の印象評価、季節の印象評価の関係を考察す るため、それぞれの類型の相互関係を考察した。

(1)多くの色が見えることで明るい時間印象になる。

(2)［黄色］は［夕方］の印象になる傾向がある。

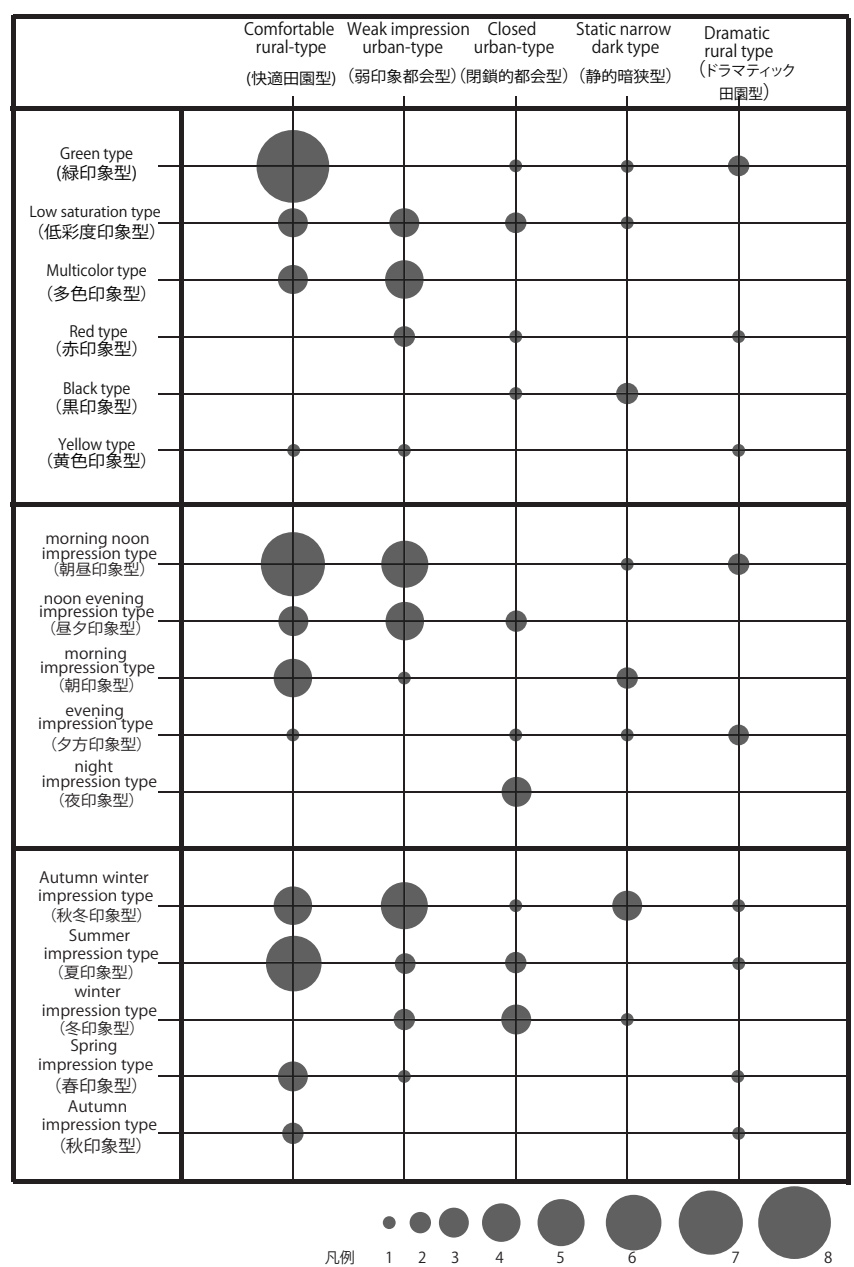

Fig.9 Summary of Impression Evaluation and Psychological Evaluation 
(3) [春］の印象を与えるには [緑］は効果的であるが、［緑］の印象 で季節の印象が決まるわけではない。

(4)［黒］の印象が強いと［秋］と［冬］の印象になる傾向がある。

4 ) 心理的評価と色の印象評価、時間の印象評価、季節の印象評価の

関係を考察するため、それぞれの類型の相互関係を考察した。

(1)多くの色を使うことで＼cjkstart明るい感じ>などのポジティブな評価に なる。

(2) [ 緑 ] の印象が強いと<明るい感じ $><$ 広々した感じ $><$ 澄んだ 感じ>の心理的評価が高くなる傾向がある。

(3) [ 黒 ] [ 灰色 ] の印象が強いと<暗い感じ $><$ 狭い感じ $><$ 濁った 感じ>の様にネガティブな評価が高くなる傾向がある。

建築空間の二次的な表現として西洋絵画を対象によ゙の色、時間、 季節に属するのかをまとめてみると（Fig. 9)、その心理的な評価の 空間表現として、概ね以下の傾向が読み取れる。

対象絵画 39 点の内もつとも多いのが〈快適田園型〉の 15 点であり、 緑の印象が強く、朝昼で、季節が夏の印象のものは、明るく、広々 とした澄んだ評価を与える。次いで、〈弱印象都会型〉が 10 点であり、 多くの色で印象づけられ、朝昼で秋冬の印象を与えるものは、明るく、 都会的な評価を与える。さらに、冬の夜の場合は、暗くて、狭い評 価となる傾向が見られるなど空間表現の手がかりを得た。

注

注 1) 心理的評価分析 : SD 法を用い西洋絵画に描かれた空間表現を人々がどの ように感じているのか 31 の評価尺度を用いた実験を行った。SD 法による 心理的評価実験で得た心理量から、いくつかの特徵的な心理評価の型を 抽出するため心理量を類似度としたクラスター分析を行った。これによ り5つのタイプに類型化した。それらをP1: 弱印象都会型、P2: 快適田園型、 P3：ドラマティック田園型、P4：静的暗狭方、P6：閉鎖的都会型と命名した。

注 2) 印象評価 : 指摘法を用い絵画の空間の雾囲気を評定するときに、被験者 にその雾囲気を形成していると思われるエレメント、本研究では色を、 数に制限なく指摘、記録してもらい分析を行った。 建築学科と建築・デザイン学科の学生男性 22 名、女性 28 名

注 3)「橙」と「オレンジ」はJIS 慣用色名において同じマンセル值を示し、ま た区別される場合においてもわずかな差しかないためすべて「橙」とし てあつかっている。

注 4) クラスター分析における類似度間の距離の算出方法は、ユークリッド距 離とする (解析ソフト SPSS)

注 5) 実験で出力したものは、絵画の選定に使用した参考文献を参考にし、ネッ 卜上から高解像度でなおかつ参考文献と同一色であるかを確認したもの を実験で使用した。

注 6) 本研究での空間とはあくまで絵画において表現された建物、景観、風景 を総じて空間のイメージとして捉えている。

\section{参考文献}

1) Matsushita,K. and Tsumita,H.:Study on evaluation of cognition on the twodimensional representation of architectural elements in western paintings, Journal of Architecture and Planning (Transactions of AIJ),Vol. 80, No. 717, pp.24592467, 2015.11 (in Japanese)

松下希和, 積田洋 : 西洋絵画に描かれた建築要素の二次元的な構成の認 知評価の研究, 日本建築学会計画系論文集, 第 80 巻, 第 717 号, pp. 24592467, 2015. 11

2) Matsushita,K.and Tsumita,H.:Study of Psychological Evaluaion and Twodimentional Composition of Architectural Elements on the Western Paintings Part1,Summaries of Technical Papers of Annual Meeting,Architectural Institute of Japan, Architectural Planning and Design,pp. 603-604, 2015.09(in Japanese) 松下希和, 積田洋: 西洋絵画における心理的評価と建築要素や空間の二 次元的な構成についての研究 西洋絵画における建築要素と二次元的構 図の印象評価の研究 (その1), 日本建築学会大会学術講演梗概集, 建築 計画 , pp. 603-604, 2015. 09

3) Matsushita,K.:Study on relationship between psychollogical evaluation and compositional characteristics of spatial representations in westsrn peintings,Journal of Architecture and Planning (Transactions of AIJ), No. 721, pp.593-602,2016. 03 (in Japanese)

松下希和：西洋絵画における空間表現の心理的評価と構図特性との関係 の研究, 日本建築学会計画系論文集, No. 721, pp. 593-602, 2016. 03

4) Yoshimoto,M.and Tsumita,H.and Matsushita,K.:Relations between the impression evaluation and the psychological evaluation of color, time and season on the Western paintings Part5,Summaries of Technical Papers of Annual Meeting, Architectural Institute of Japan,pp.561-562, 2016.08(in Japanese)

吉本美江, 積田洋, 松下希和：西洋絵画の心理評価と色彩・時間・季 節の印象評価の関係 西洋絵画における建築要素と二次元的構図の印 象評価の研究 (その 5), 日本建築学会大会学術講演梗概集, 建築計画, pp. 561-562, 2016. 08

5) Kuroda,M:Perspective describing space,shokokusha,1992.02(in Japanese) 黒田正巳：空間を描く遠近法, 彰国社, 1992.02

6) Miwa,Y. and Natsume,Y. and Wakayama,S.:URBAN AND ARCHITECTURAL SPACE IN THE WESTERN PAINTINGS : From renaissance to neoclassicism,Journal of Architecture and Planning (Transactions of AIJ), No. 631, pp.59-64, 2007.03(in Japanese)

三輪祐仁, 夏目欣昇, 若山滋 : 西洋絵画の中の都市・建築空間ールネサ ンスから新古典主義一, 日本建築学会計画系論文集, No. 613, pp. 59-64, 2007. 03

7) Miwa,Y. and Natsume,Y. and Wakayama,S.:Architectural space in the 17th century Netherlands paintings,Journal of Architecture and Planning (Transactions of AIJ), No. 593、pp.73-78, 2005.07

(in Japanese)

三輪祐仁, 夏目欣昇, 若山滋 : 17 世紀オランダ絵画の中の建築空間, 日 本建築学会計画系論文集, No. 593,pp. 73-78, 2005.07

8) Fukumoto,A. and Wakayama,S. and Natsume,Y.:Memory of space in pictures and the novel of Giorgio de Chirico,Summaries of Technical Papers of Annual Meeting, Architectural Institute of Japan,Architectural history and design,F2,pp.785-786, 2009.07(in Japanese)

福元彩, 若山滋, 夏目欣昇: ジョルジョ・デ・キリコの絵画と小説にお ける空間 $の$ 記憶, 日本建築学大会学術講演梗概集, F-2, 建築歴史・意 匠, pp. 785-786, 2009. 07

9) Oota,K.:On how to draw and classify line perspective in F. L. Lite's house Part 1,AIJ Journal of Technology and Design,No,9、pp187 - 191, 1999.12(in Japanese)

太田 邦夫 :F. L. ライトの住宅における線透視図の描かれ方と類型化につ いて その 1, 日本建築学会技術報告集, No. 9, pp187-191, 1999. 12

10) Fukudome,Y. and Sugimoto,T.:Study on the Perspective Representation observed in Dutch Pictures in the 17th Century(Transactions of AIJ),No.13, pp. "907-1"“907-4”, 2008.03(in Japanese)

福留吉絵, 杉本俊多:17 世紀オランダ絵画に見られる透視図法に関する 研究、日本建築学会中国支部研究報告集、No. 13, pp. “907-1”-“907-4”, 2008. 03

11) Davies, P.J.E, et al: Janson's History of Art, Eighth edition, Prentice Hall,2011 Kleiner, F.S., et al: Gardner's Art Through Ages, Twelfth edition, Wardsworth / Thomson Learning,2005

Takashina,S. Supervision:Color version Western art historical augmentation new edition, Bijyutusyuppansya,2002.12(in Japanese) 高階秀爾監修: カラー版西洋美術史 増補新装版, 美術出版社, 2002.12

12) Nagai,I. and Kishima,T.:High School Art I / II, Nihon Bunkysyuppan, 2014.01(in Japanese)

永井一正，木島俊介監修：高校美術 I / II ，日本文教出版 2014.01

13) Architectural Institute of Japan edited: Survey and analysis method for building city planning, Inoue syoin, 2002.05(in Japanese)

日本建築学会編: 建築・都市計画のための 調査. 分析方法, 井上書 院, 2002.05

14) Funakoshi, T. Tsumita, H.: Space grammar for architectural city planning, shoukokusya, 2011.8(in Japanese)

船越徹, 積田洋 : 建築都市計画のための空間の文法, 彰国社, 2011.08 


\title{
IMPRESSION EVALUATION OF COLOR, TIME AND SEASON \\ IN WESTERN PAINTINGS ANALYSIS OF RELATIONSHIP OF PSYCHOLOGICAL EVALUATION
}

\author{
Hiroshi TSUMITA*1, Saki SHIBUYA *2 and Mie YOSHIMOTO *2 \\ ${ }^{* 1}$ Prof., Dept. of Architecture, School of Science and Technology for Future, TDU, Dr.Eng. \\ ${ }^{* 2}$ Grad. Student, Dept. of Architecture, Faculty of Science and Technology for Future, TDU, M.Eng.
}

Architecture space is three dimensional, but the method to represent them is often in two-dimensional mediums of photograph or perspective drawings. The perspective view is effective in expressing a visual performance of the building. Therefore I clarify the influence that neighboring scenes and atmospheres which give in an impression in Architecture drawing. And it is intended to obtain basic information to improve architectural and spatial representation.

39 pieces of representational painting which a building was depicted in the European Paintings from the Renaissance to modern times are selected as the object of the analysis. 50 students were asked to rate the psychological evaluation and the impression evaluation of a color, time, the season.

Result of examining the impression evaluation of color. Total has been selected 24 colors.

Therefore I performed the impression evaluation experiment on color, time, season. I performed cluster analysis from those results, and the paintings were classified into six types by the impression evaluation of the color. The colors selected from many peoples, "Green impression type", "Red impression type", "Yellow impression type", "Black impression type". It selected from many peoples [Black], [Gray], [White], with low saturation such "Low saturation impression type". It classified into different impression "Multicolor impression type" by the people.

The pictures were classified in five types by the impression evaluation of the time. The time selected from many peoples, "Morning noon impression type" , "Morning impression type", "Noon evening impression type", "Evening impression type", "Night impression type".

The pictures were classified in five types by the impression evaluation of the season. The season selected from many peoples, "Summer impression type", "Spring impression type", "Winter impression type", "Autumn impression type", "Autumn winter impression type".

In the psychological evaluation and the color impression evaluation, first "Multicolor impression type" positive evaluation was gathered in the high "Weak impression urban-type" "Comfortable rural-type". From this fact, when many of the color is used, it tends to give a positive impression. In addition, Is the many "Green impression type" is a high rating the $<$ Idyllic feel $><$ Spacious feel $><$ Feeling clear $>$ is "Comfort rural-type". Therefore, by a strong impression of the [Green], we know that there is a tendency that those of psychological evaluation are high. Is the many "Black impression type" is a high rating the $<$ Dark feel $><$ Narrow feel $><$ High evaluation of feeling $>$ is "Static Narrow dark type", "Closed urban-type". When [Black] [Gray] are used, it tends to give the negative impression.

In the psychological evaluation and the time impression evaluation, A high rating of $<$ Bright feel $>$ were "Weak impression urban-type", "Comfortable rural-type" were many answers of [Morning] from [Noon]. High ratings of $<$ Dark feel $>$ were" closed urban-type" were many answers of [Evening] from the [Night]. Similarly high ratings of $<$ Dark feel $>$ were "Static narrow dark type" were many answers of [Morning] and [Evening].

In the psychological evaluation and the season impression evaluation,the higher the evaluation of $<$ Bright feel $>$ and Architecture impression is "Weak impression urban type", picture of this type are mostly "Fall or winter impression type". This is the presence of the A trees is considered to be because it is sparse. "Static dark narrow type" and "Closed urbantype" are concentrated in "Autumn winter impression type" and "Winter impression type". Earlier they have been found to be a strong impression of [Black] and [Gray].From this fact, when the strong impression of "[Black] [Gray]", when the season of the impression tends to be [Autumn] and [Winter]. 